\title{
Preliminary studies on possibility of using the herbarium specimens of mosses in the assessment of heavy metal pollution in Katowice (Silesian Upland, Poland)
}

Patryk Ochota \& Adam Stebel

Preliminary studies on possibility of using the herbarium specimens of mosses in the assessment of heavy metal pollution in Katowice (Silesian Upland, Poland). - Čas. Slez. Muz. Opava (A), 62: 59-64, 2013.

\begin{abstract}
The paper presents the preliminary results of using the herbarium specimens of selected mosses (Brachythecium rutabulum (Hedw.) Schimp., B. salebrosum (F.Weber \& D.Mohr) Schimp. and Hypnum cupressiforme Hedw, for assessment of changes in the heavy metals pollution in Katowice town. For the initial studies lead and cadmium have been chosen, which are among the most toxic heavy metals. Specimens originate from two periods: the nineties of $20^{\text {th }}$ century and from 2012 . To verify the correctness of assumption the control samples were selected from the collection of mosses from the Białowieża Primeval Forest considered as a "clean" part of Poland, in the nineties of $20^{\text {th }}$ century, stored in the same conditions. The results obtained in these investigations confirm the possibility of application of herbarium specimens of mosses in the biological assessment of changes in lead and cadmium contamination.
\end{abstract}

Key words: mosses, cadmium, lead, heavy metal, pollution, biological assessment, Silesian Upland, Katowice, Silesia Province, Poland

\section{Introduction}

Several moss species have been used as a biomarker of environmental pollution with chemicals such as heavy metals and some organic compounds. In Europe environmental monitoring of heavy metals with mosses as indicators started in the second half of the $20^{\text {th }}$ century and has been conducted till this time (i.e. Hermes et al. 2008, 2010; Kleppin et al. 2008; Šakalys et al. 2009). In Poland, this kind of investigation has been conducted for several dozen of years (i.e. Grodzińska 1978, 1980; Ciepał 1992, 1999; Szarek-Łukaszewska et al. 2002; Grodzińska et al. 2003; Dmuchowski et al. 2009; Kosior et al. 2010; Ochota et al. 2012).

The observation of changes of air pollution over 50, 100 or even more years is very interesting. This type of research can be carried out using previously collected and stored moss materials in herbaria. In some papers information of this possibility were published (Herpin et al. 1997; Weiss et al. 1999; Peñuelas, Filella 2002; Shotbolt et al. 2007; Saxena et al. 2008; T. Cao et al. 2008; Wojtuń et al. 2012).

This paper provides information on using herbarium specimens of mosses housed in the Herbarium of the Department of Pharmaceutical Botany of Medical University of Silesia in Katowice (SOSN) for biological assessment of changes in the heavy metals pollution in the Katowice city.

\section{Study area}

Silesian Upland is a large region, covering over 4000 square kilometres in southern Poland. It is the most urbanized and industrialized area, with strongly changed natural environment. Heavy industry, mainly coalmining and metallurgy, has developed in this area since the end of the $18^{\text {th }}$ century. In the second of half of $20^{\text {th }}$ century intense urbanization and industrialization have began. Considering lower ecological norms that time, it caused water, air and soil pollution on unprecedented scale. Since the end of $20^{\text {th }}$ century air quality has improved as a result of economic changes that have reduced the share of industry in the Polish economy.

Katowice is the largest city within the Upper Silesian Industrial District, covering an area of about $165 \mathrm{~km}^{2}$ with approximately 300000 inhabitants. The relief consists of small hills, rarely exceeding above $300 \mathrm{~m}$ a.s.l., 
and depression filled with Pleistocene deposits, lying between them. The human impact is the main factor shaping the landscape of Katowice

causing the disappearance of natural features and the creation of anthropogenic ones (pits, embankments, mining and metallurgic waste tips). The forest areas in Katowice, quite large especially in southern part, represent in overwhelming majority managed forests (Fig 1), mainly monocultures of few tree species, first of all Scots pine Pinus sylvestris L.

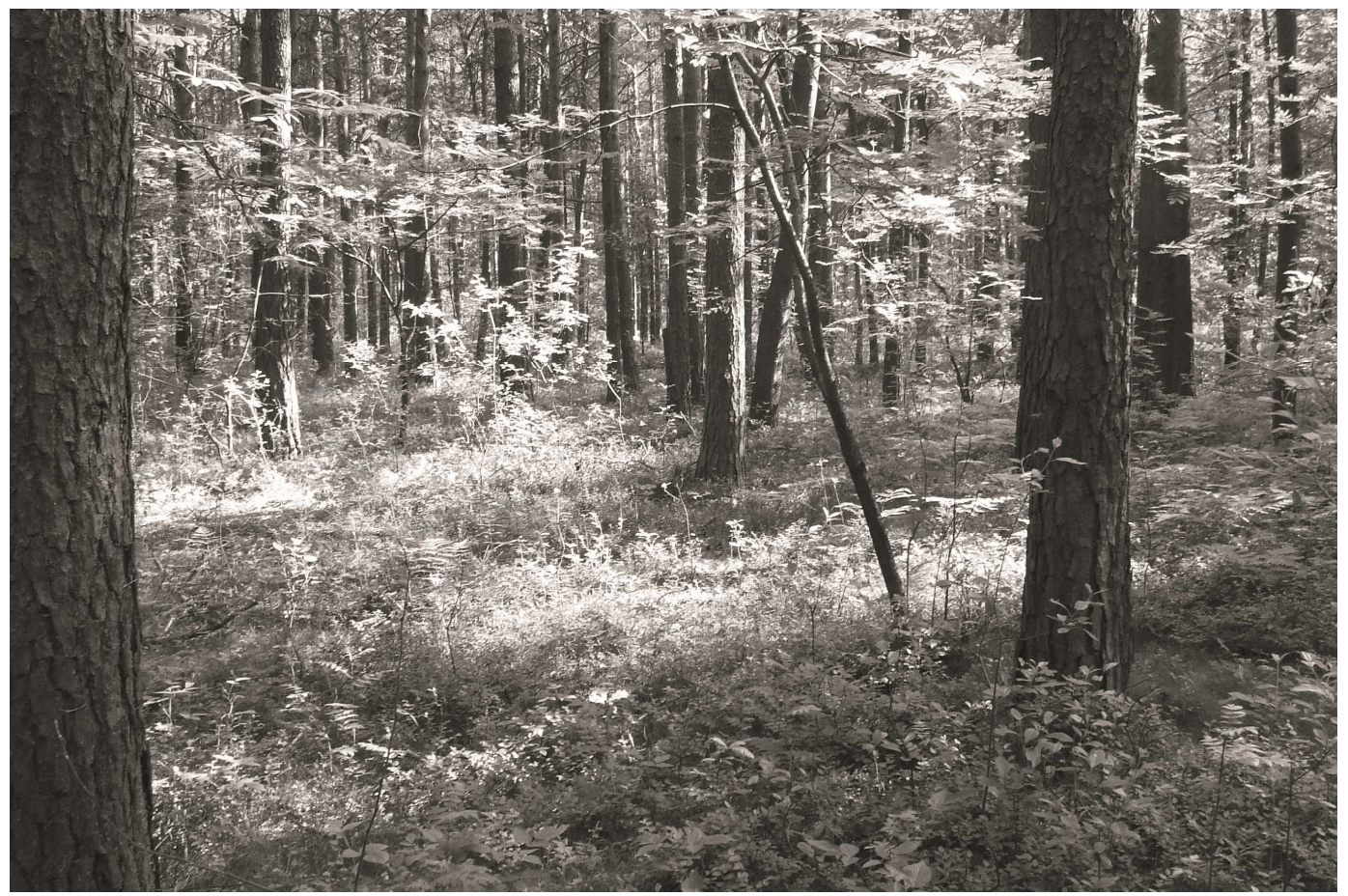

Fig 1: Forest near Katowice-Piotrowice (photo by A. Stebel, 8 June 2010).

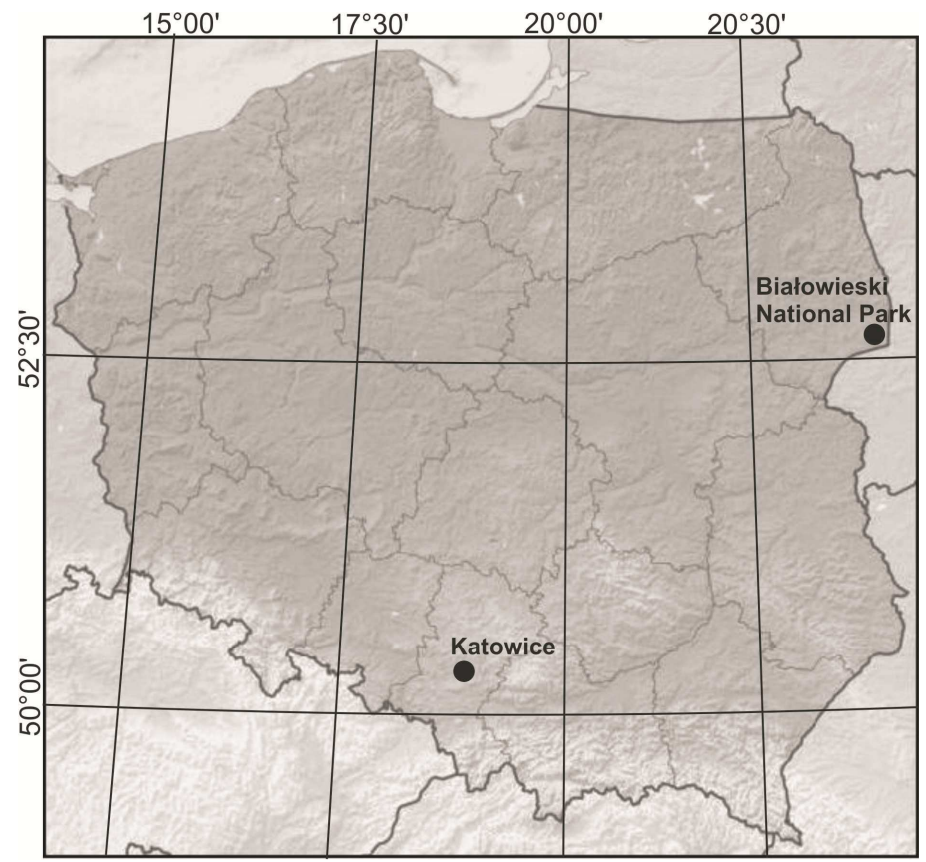

Fig 2: Collecting sites of mosses.

\section{Aim of the study and research methods}

The purpose of the investigation was the verification of usability of herbarium specimens of selected moss species in assessment of changes of heavy metals pollution in Katowice. Area of Katowice is very well 
bryologically known and a lot of moss specimens, collected since early seventies of $20^{\text {th }}$ century are stored in the Herbarium of the Department of Pharmaceutical Botany of Medical University of Silesia in Katowice (SOSN). For studies three species have been chosen, namely Brachthecium rutabulum (Hedw.) Schimp., Brachythecium salebrosum (F.Weber \& D.Mohr) Schimp. and Hypnum cupressiforme Hedw. They are common species in Katowice, growing in various habitats. Herbarium specimens as well as currently collected ones origin from epiphytic, rarely epixylic and epilithic habitas located within forest communities. Mosses used in this investigation origin from two periods: the nineties of $20^{\text {th }}$ century and from 2012. Specimens from the first period were collected as a documentation of bryological works of Fojcik and Stebel (2001). They are stored in paper envelopes, which are arranged in cardboard folders, closed in wooden lockers. To verify the correctness of assumption, that these specimens were not contaminated of heavy metals during their storage, the control samples were necessary. They are selected from the collection of mosses made by J. Żarnowiec from Białowieża Primeval Forest (Żarnowiec 1995), considered as a "clean" part of Poland, in the nineties of $20^{\text {th }}$ century, stored in the same conditions (Fig 2). For the initial studies lead and cadmium have been chosen, which are among the most toxic heavy metals and their mining and processing industry occurred in the vicinity of Katowice. In the future it is planned to mark other elements.

Dry samples of moss were cleaned of foreign components, including the soil, and dried in air ambient temperature. After drying the samples were mineralized using 69.0-70.0\% nitric acid 'BAKER INSTRAANALYZED for Trace Metals Analysis'. Content of $\mathrm{Pb}$ and $\mathrm{Cd}$ were determined by atomic absorption spectrometry with electro-thermal atomization (ETAAS) using ZL 4100 Perkin Elmer with the Zeeman's method of background correction.

Prior to determination of $\mathrm{Pb}$ and $\mathrm{Cd}$ content in mosses, the method was validated using Certified Reference Material of mixed Polish herbs 'INCT-MPH-2' (Tab 1).

Tab 1: Contents measured and certificated $\mathrm{Pb}$ and $\mathrm{Cd}$.

\begin{tabular}{|c|c|c|}
\hline & $\mathrm{Pb}[\mu \mathrm{g} / \mathrm{g}]$ & $\mathrm{Cd}[\mu \mathrm{g} / \mathrm{g}]$ \\
\hline Measured content & 2.20 & 0.191 \\
\hline Certificated content & $2.16 \pm 0.23$ & $0.199 \pm 0.015$ \\
\hline
\end{tabular}

\section{Results}

In total, 19 samples were tested, 16 from Katowice and 3 from Białowieża. Due to the small amount of material, metal content in the herbarium samples was measured once, whereas in samples collected in 2012 twice.

Results of measurements of selected moss samples from stations from Katowice and Białowieski National Park are set in figures 3 and 4.

Contents of lead and cadmium in the samples collected in Białowieski National Park are several times lower than in samples gathered at the same time in Katowice. It indicates, that conditions of specimens preservation in herbarium do not influence the degree of lead and cadmium contamination. It is worth mentioning that in samples from Białowieski National Park contents of lead in Hypnum cupressiforme is clearly higher than in specimens of Brachythecium, which supports observations that this species accumulates lead better than other mosses (Otwos et al. 2003). Inversely, it seems that Hypnum cupressiforme is worse cadmium accumulator than investigated mosses from the genus Brachythecium, but this observations must be tested on the greater part of samples.

Generally speaking, degree of contamination of lead and cadmium in Katowice slightly decreases, but varies in particular quarters of Katowice. The main reasons are changes in management on this area. At the beginning of $21^{\text {th }}$ century a lot of heavy industry works (coal mines, steelworks) were closed, but road network and flat and house building have strongly increased. Preliminary results obtained in these investigations confirm the possibility of application of herbarium specimens of mosses in the biological assessment of changes in lead and cadmium contamination. Of course, some local differences between particular localities and species are recorded. These problems will be the subject of the further studies. 


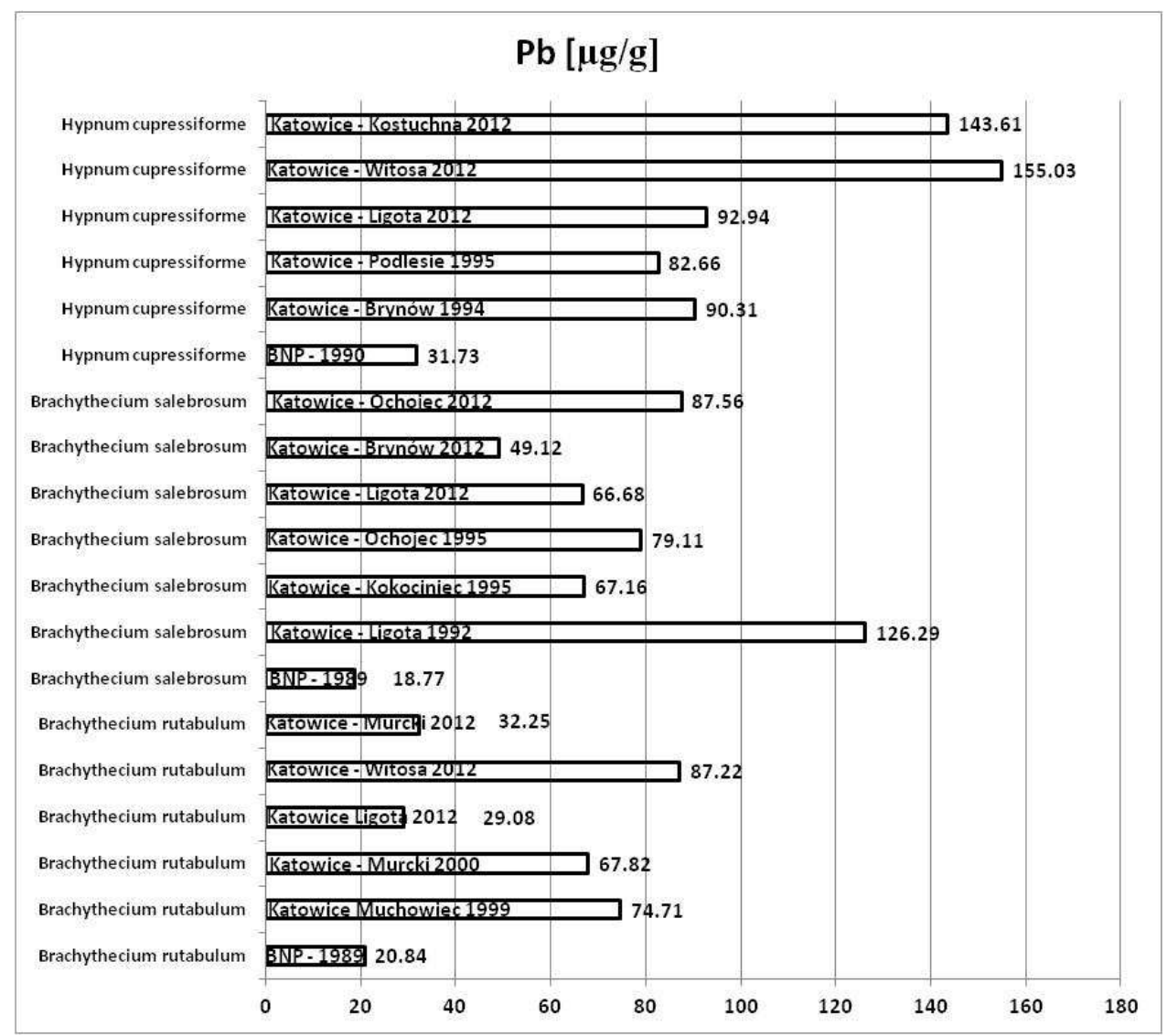

Fig 3: Comparison of lead content in moss samples.

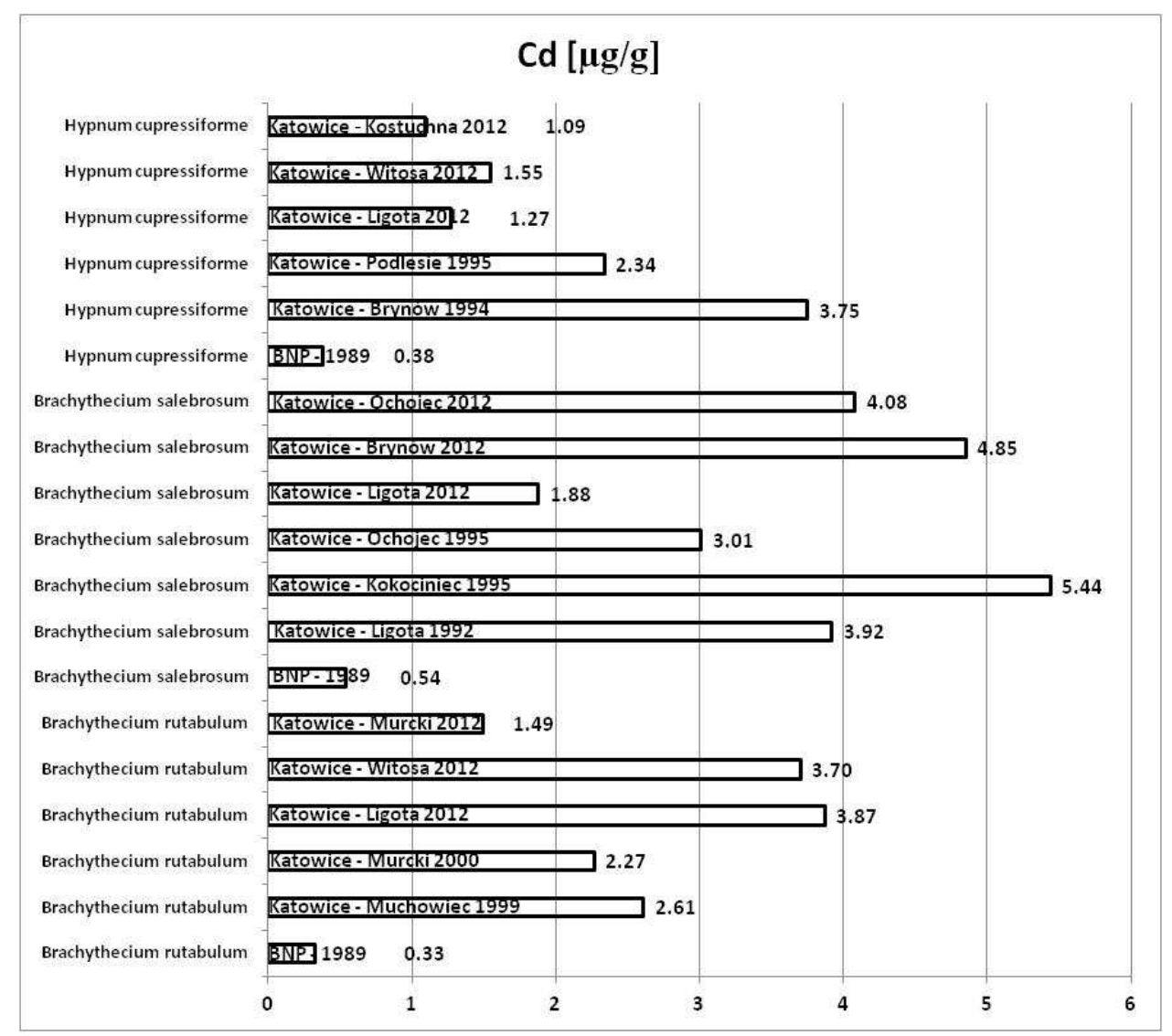

Fig 4: Comparison of cadmium content in moss samples. 


\section{References}

Cao T., An L., Wang M., Lou Y., Yu Y., Wu J., Zhu Z., Qing Y. \& Glime J. (2008): Spatial and temporal changes of heavy metal concentrations in mosses and its indication to the environments in the past 40 years in the city of Shanghai, China. - Atmospheric. Environment 42(21): 5390-5402.

Ciepał R. (1992): Przenikanie S, Pb, Cd, Cu, Fe do biomasy oraz gleby ekosystemu leśnego na przykładzie wschodniej części województwa katowickiego. - Prace Naukowe UŚ Nr 1319, Uniwersytet Śląski, Katowice: $1-106$.

- (1999): Kumulacja metali ciężkich i siarki w roślinach wybranych gatunków oraz glebie jako wskaźnik stanu skażenia środowiska terenów chronionych województw śląskiego i małopolskiego. - Prace Naukowe UŚ $\mathrm{Nr}$ 1774, Uniwersytet Śląski, Katowice: 1-163.

Dmuchowski D. \& Bytnerowicz A. (2009): Long-term (1992-2004) record of lead, cadmium, and zinc air contamination in Warsaw, Poland: Determination by chemical analysis of moss bags and leaves of Crimean linden. - Environmental Pollution 157(12): 3413-3421.

Fojcik B. \& Stebel A. (2001): Struktura ekologiczna i przestrzenna brioflory miasta Katowice. - Materiały Opracowania, Centrum Dziedzictwa Przyrody Górnego Śląska w Katowicach 5: 1-128.

Grodzińska K. (1978): Mosses as bioindicators of heavy metal pollution in Polish National Parks. - Water Air Soil Pollution 9: 83-97.

- (1980): Zanieczyszczenie polskich parków narodowych metalami ciężkimi. - Ochrona Przyrody 43: 9-27.

Grodzińska K., Frontasyeva M., Szarek-Łukaszewska G., Klich M., Kucharska-Fabiś A., Gundorina S.F. \& Ostrovnaya T.M. (2003): Trace element contamination in industrial regions of Poland studied by moss monitoring. - Environmental Monitoring and Assessment 87: 255-270.

Hermes H., Norris D.A., Koerber G.R., Buse A., Steinnes E. \& Ruehling A. (2008): Temporal trends (1990-2000) in the concentration of cadmium, lead and mercury in mosses across Europe. - Environmental Pollution 151(2): 368-376.

Hermes H., Norris D.A., Steinnes E., Kubin E., Piispanen J., Alber R., Aleksiayenak Y., Blum O., Coskun M., Dam M., De Temmerman L., Fernández J.A., Frolova M., Frontasyeva M., González-Miqueo L., Grodzińska K., Jeran Z., Korzekwa S., Krmar M., Kvietkus K., Leblond S., Liiv S., Magnússon S.H., Mankovská B., Pesch R., Rühling Å., Santamaria J.M., Schröder W., Spiric Z., Suchara I., Thöni L., Urumov V., Yurukova L. \& Zechmeister H.G. (2010): Mosses as biomonitors of atmospheric heavy metal deposition: Spatial patterns and temporal trends in Europe. - Environmental Pollution 158(10): 3144-3156.

Herpin U., Markert B., Weckert V., Berlekamp J., Friese K., Siewers U. \& Lieth H. (1997): Retrospective analysis of heavy metal concentrations at selected locations in the Federal Republic of Germany using moss material from a herbarium. - The Science of the Total Environment 205: 1-12.

Kleppin L., Pesch R. \& Schroeder W. (2008): CHAID Models on boundary conditions of metal accumulation in mosses collected in Germany in 1990, 1995 and 2000. - Atmos. Env. 42 (21): 5220-5231.

Kosior G., Samecka-Cymerman A., Kolon K. \& Kempers A.J. (2010): Bioindication capacity of metal pollution of native and transplanted Pleurozium schreberi under various levels of pollution. - Chemosphere 81: 321-326.

Ochota P., Prokopowicz A., Kosmider L., Choina M., Stebel A. \& Sobczak A. (2012): Heavy metals in moss samples exposed to the atmospheric dust after eruption of Eyjafjallajökull volcano. Medycyna Środowiskowa 15(1): 21-26.

Otwos E., Pazmandi T. \& Tuba Z. (2003): First national survey of atmospheric heavy metal deposition in Hungary by the analysis of mosses. - The Science of the Total Environment 309: 151-160.

Peñuelas J. \& Filella I. (2002): Metal pollution in Spanish terrestrial ecosystems during the twentieth century. Chemosphere 46: 501-505.

Saxena D.K., Srivastava K. \& Singh S. (2008): Retrospective metal data of the last 100 years deduced by moss, Barbula sp. from Mussoorie city, Garhwal Hills, India. - Current Science 94 (7): 901-904.

Shotbolt L., Büker P. \& Ashmore M.R. (2007): Reconstructing temporal trends in heavy metal deposition: Assessing the value of herbarium moss samples. - Environmental Pollution 147: 120-130.

Szarek-Łukaszewska G., Grodzińska K. \& Braniewski S. (2002): Heavy metal concentration in the moss Pleurozium schreberi in the Niepołomice forest, Poland: changes during 20 years. - Environ. Monit. Assess. 79: 231-237.

Šakalys J., Kvietkus K., Sucharova J., Suchara I. \& Valiulis D. (2009): Changes in total concentrations and assessed background concentrations of heavy metals in moss in Lithuania and the Czech Republic between 1995 and 2005. - Chemosphere 76 (1): 91-97.

Weiss D., Shotyk W., Kramers J. D. \& Gloor M. (1999): Sphagnum mosses as archives of recent and past atmospheric lead deposition in Switzerland. - Atmospheric Environment 33: 3751-3763. 
Wojtuń B., Samecka-Cymerman A., Kolon K. \& Kempers A.J. (2012): Decreasing concentrations of metals in Sphagnum mosses in ombrotrophic mires of the Sudety mountains (SW Poland) since late 1980s. - Chemosphere (in press).

Żarnowiec J. (1995): VII. Bryopsida. In: Faliński J.B. \& Mułenko W. [eds]: Cryptogamous plants in the forest communities of Białowieża National Park. General problems and taxonomic groups analysis (Project CRYPTO). Phytocoenosis 7 (N.S.). - Archivum Geobotanicum 4: 47-61.

Authors' addresses: Patryk Ochota, Department of Chemical Hazards and Genetic Toxicology, Institute of Occupational Medicine and Environmental Health, ul. Kościelna 13, 41-200 Sosnowiec, Poland e-mail: p.ochota@imp.sosnowiec.pl

Adam Stebel, Department of Pharmaceutical Botany, Medical University of Silesia in Katowice, ul. Ostrogórska 30, 41-200 Sosnowiec, Poland; e-mails: astebel@ sum.edu.pl. 